\title{
Near-bottom particulate matter dynamics in the Nazaré submarine canyon under calm and stormy conditions
}

Jacobo Martín ${ }^{1}$, Albert Palanques ${ }^{1}$, João Vitorino ${ }^{2}$, Anabela Oliveira ${ }^{2}$, Henko de Stigter $^{3}$

1. Instituto de Ciencias del Mar (CSIC). Paseo Marítimo de la Barceloneta, 37-49, Barcelona, E-08003, Spain.

2. Instituto Hidrográfico. Rua das Trinas, 49. 1249-093. Lisboa. Portugal.

3. Royal Netherlands Institute for Sea Research (NIOZ), Texel, The Netherlands.

\begin{abstract}
Two mooring lines equipped with near-bottom sediment traps were deployed in the axis of the Nazaré submarine canyon at $\sim 1600$ and $\sim 3300 \mathrm{~m}$ depth respectively. We studied time series of particle flux, composition (biogenic silica, carbonates, organic matter and lithogenic fractions), granulometry, mineralogy and ${ }^{210} \mathrm{~Pb}$ concentration of particulate matter over five sediment trap deployments between October 2002 and December 2004. Current meters equipped with turbidimeters were also deployed at trap depths to monitor the water flow, temperature, salinity and suspended particle concentration. The composition of the collected particles was fairly constant year-round, dominated by the lithogenic fraction and with $\mathrm{OC} / \mathrm{N}$ ratios in the range 11-30, suggesting an important terrigenous influence inside the canyon. The results show contrasting dynamic environments in the upper (1600 m depth) and middle (3300 m depth) canyon. High current speeds (spring tides up to $80 \mathrm{~cm} \mathrm{~s}^{-1}$ ) and high apparent mass fluxes of particulate matter (mean $65 \mathrm{~g} \mathrm{~m}^{-2} \mathrm{~d}^{-1}$; maximum $265 \mathrm{~g} \mathrm{~m}^{-2} \mathrm{~d}^{-1}$ ) are permanent at the shallowest
\end{abstract}


station. At the deepest site, fluxes were below $10 \mathrm{~g} \mathrm{~m}^{-2} \mathrm{~d}^{-1}$ most of the time and the annual flux was governed by events of sharp flux increase. Storms affecting the continental shelf during autumn and winter are a major driver of down-canyon dispersal of sediments to the middle canyon and beyond. Important nepheloid activity developed inside the canyon in response to storms with significant wave heights between 4 and 6 $\mathrm{m}$, as testified by turbidimeters deployed in midwater and near the seabed at $1600 \mathrm{~m}$ water depth. On three occasions during the study period, significant wave heights of incident storms surpassed $7 \mathrm{~m}$, leading to notable episodes of down-canyon transport that were clearly observed in the middle canyon. During one of these stormy periods (January 2003) a sediment gravity flow transporting unusual quantities of sand and coastal plant debris was observed at $3200 \mathrm{~m}$. However, a storm with significant wave heights as low as $5 \mathrm{~m}$ was apparently able to trigger a sediment gravity flow reaching beyond the middle canyon. The role of storms in the offshore dispersal of sediments is clearly relevant but seems to be modulated by synergic factors such as river flooding.

Keywords: Particulate flux; Continental margins; Submarine canyon; Northeast Atlantic; Iberian Margin; Nazaré Canyon 


\section{Introduction}

In comparison to non-dissected open margins, steep submarine canyons intersecting the continental shelf offer a faster route for the offshore export of bulk and organic material to the deep sea, with important consequences for issues including climate modulation through the sequestration of atmospheric carbon, the nourishment of deep-sea benthic ecosystems or the fate of pollutants (Pfannkuche, 1993; Puig et al., 1999; Canals et al., 2006). In spite of decreased sediment supply since the Holocene transgression, many contemporary submarine canyons are active sedimentary settings where significant concentration and off-shelf export of particulate matter takes place (Hickey et al., 1986; Puig and Palanques, 1998; Palanques et al., 2006a; Canals et al., 2006; Martín et al., $2006,2007)$. Some canyons remain active owing to their proximity or direct connection to fluvial systems (e.g. Walsh and Nittrouer, 2003; Khripounoff et al., 2003). However, proximity to river mouths is not a prerequisite for canyon activity. On narrow, tectonically active margins, canyon heads cross the continental shelf, intercepting and trapping the sediment transported by along-shore currents, which is delivered to the deep sea by the action of storms, earthquakes, spontaneous sediment destabilization and even human action (Lewis and Barnes, 1999; Mulder et al., 2001; Xu et al., 2004; Palanques et al., 2006a; Martín et al., 2008).

The role of submarine canyons as preferential repositories and offshore conduits of terrestrial particles was one of the main issues addressed by the EUROSTRATAFORM program, the general objective of which was to relate contemporary sedimentary processes to the preservation of sedimentary strata on European continental margins. The Nazare Canyon, an impressive submarine incision that bisects the full width of the 
Western Iberian Margin, was selected as a suitable site to study the dynamic processes inside modern submarine canyons. The head of the Nazaré Canyon penetrates deep into the continental shelf, virtually reaching the coastline. As a consequence, and despite the absence of major rivers opening to the adjacent coast, the upper canyon acts as a sink for sediment particles transported by the general southward coastal drift (Oliveira et al., 2007). Evidence for sedimentary activity inside the canyon includes nepheloid layers hundreds of meters thick with particle loads up to $10 \mathrm{mg} \mathrm{l}^{-1}$ in the upper canyon (De Stigter et al., 2007) and accumulation rates of bulk and organic matter orders of magnitude higher than those on the open slopes of the West Iberian Margin at similar depths (Van Weering et al., 2002; Van Der Zee et al., 2002). Based on the activities of the short-lived radionuclide ${ }^{234} \mathrm{Th}$ in recent sediments, Schmidt et al. (2001) also confirmed the high contemporary activity of the Nazaré Canyon but were unable to distinguish continuous from pulsed sedimentary inputs. More recent studies have shown an event-driven sedimentary regime inside the canyon (De Stigter et al., 2007; Lastras et al., 2009). Storms have been invoked as a plausible triggering mechanism of major recent down-canyon transport events (Van Weering et al., 2002; Oliveira et al., 2007; De Stigter et al., 2007), although direct observations of such connection are still pending.

In the framework of EUROSTRATAFORM, two mooring lines equipped with nearbottom sediment traps, current meters and turbidimeters were deployed in the axis of the Nazaré Canyon, at 1600 and 3300 m nominal depths respectively. In this work, we present and discuss results of the composition and apparent fluxes of settling particles collected by sediment traps and the hydrographical and hydrodynamic parameters recorded by current meters between October 2002 and December 2004. The temporal 
and spatial variability of near-bottom particle flux and composition at the study sites, as well as the role of shelf storms as driving mechanisms for the observed variability, are discussed.

\section{Regional setting}

\subsection{The West Iberian Margin}

The continental margin along the western side of the Iberian Peninsula is shaped by a relatively narrow shelf, indented by several steep submarine canyons. Among them, the Nazaré Canyon (Fig. 1) is the largest and most deeply incised. The hydrography of the water column over the West Iberian Margin is complex (Van Aken, 2000). One of its most distinct features is a salinity maximum at $800-1400 \mathrm{~m}$ depth, corresponding to the Mediterranean Sea Outflow Water (MW) (Van Aken, 2000). A strong density gradient is formed between the core of MW and the overlying and underlying water masses, favouring the development of internal waves and the resuspension of fine sediments where these density discontinuities intersect the seafloor (McCave and Hall, 2002).

Over the continental slope, the water flow follows a seasonal pattern related to the Azores high pressure system (Wooster et al., 1976). During summer, the prevailing northern winds promote upwelling conditions along the west Iberian shelf (Fiúza et al., 1982). During winter, southern winds induce poleward flow over the upper slope (Frouin et al., 1990), which in turn promotes downwelling conditions along the Portuguese Margin and likewise in the Nazaré Canyon head. During most of the year, the wind and wave regimes are dominated by north-west swells with moderate 
significant wave heights between 1 and $4 \mathrm{~m}$, that nonetheless result in a significant southward sediment drift. Wave heights above $5 \mathrm{~m}$ are often linked to episodic west and southwesterly storms during autumn and winter. Return periods have been estimated as 0.3 years for typical storms and 10 years for major storms reaching significant wave heights $\geq 10 \mathrm{~m}$ (Drago et al., 1998 and references therein; Vitorino et al., 2002a).

\subsection{The Nazaré submarine canyon}

The Nazaré Canyon has been divided into several regions or domains on the basis of the succession of geomorphologic and dynamic features along the canyon's path, the exact criterion varying with the author. We will hereafter use the original description by Vanney and Mougenot (1993), who divided the Nazaré Canyon into three subunits: upper, middle and lower. The upper canyon stretches from the canyon head to approximately $1700 \mathrm{~m}$ depth ( $\sim 7 \mathrm{~km}$ offshore) along a sinuous path incised across the Portuguese margin (Fig. 1). The upper canyon axis is typically a V-shaped erosive valley with a mean axial gradient of $3.2 \%$. In the middle canyon (1700-4000 m depth; approximately 50-100 $\mathrm{km}$ from the shoreline), entrenchment, slope and sinuosity of the canyon axis decrease downstream in proportion to its increasing width (Vanney and Mougenot, 1993). In the proximal part of the middle canyon course, the canyon axis is still markedly $\mathrm{V}$-shaped and axial gradients can reach up to $8.2 \%$ at some locations. Towards the distal limit of the middle canyon, the axis evolves slowly into a U-shaped valley with a mean bathymetric gradient $\sim 2.9 \%$ (Vanney and Mougenot, 1993). Along the canyon lower course ( $>4000 \mathrm{~m}$ depth), the canyon axis slope decreases progressively from 1.9 to $0.3 \%$ till the canyon merges with the Iberian Abyssal Plain at 
approximately $5000 \mathrm{~m}$ depth. More detailed descriptions of the canyon morphology are given in Lastras et al. (2009) and Masson et al. (this issue).

The upper canyon has been identified as a temporary reservoir of particles that accumulate until sufficiently high energy conditions promote their transport down canyon (Oliveira et al., 2007). The dynamic setting near the bottom at the upper canyon is very energetic owing to intensified near-bottom tides and internal wave formation (Vitorino et al., 2005). It has been claimed that formation of density flows is the main process responsible for the redistribution of sediments along the canyon (De Stigter et al., 2007). According to De Stigter et al. (2007), only major sediment gravity flows with recurrence periods in the range of centuries can progress to the deepest reaches of the canyon, while the upper and middle canyon are swept by gravity flows at much higher, probably seasonal, frequencies.

\section{Materials and methods}

\subsection{Experimental design and moored instruments}

Two sediment traps were deployed $25 \mathrm{~m}$ above the bottom (mab) in moorings located at nominal water depths of $1600 \mathrm{~m}$ (M1) and $3300 \mathrm{~m}$ (M2), along the main axis of the Nazaré Canyon (Fig. 1). The study lasted from October 2002 to December 2004, separated into five consecutive deployments. Traps will be hereafter referred to as $\mathrm{T} 1$ (1600 m depth) and T2 (3300 m depth). Due to persistent overfilling, trap T1 was lifted to 50 mab from the third deployment onwards. Geographic positions, bottom depth, distance of traps above the seafloor and sampling dates for each deployment are given 
in Table 1. The Technicap PPS3/3 traps used in this study consist of cylindro-conical collectors with an aspect ratio $=2.5(1.0 / 0.4 \mathrm{~m})$ in its cylindrical part, and an unbaffled aperture of $0.125 \mathrm{~m}^{2}$. A set of 12 sampling cups filled with a buffered formalin solution $(5 \%, \mathrm{v} / \mathrm{v})$ are replaced at preset intervals by a programmable rotary mechanism.

It must be considered that sediment traps were originally conceived to sample the downward flux of particles at midwaters, and that flux measured by traps deployed near the seafloor may be heavily biased by particles laterally advected or uplifted from the seafloor underneath the trap (see Bonnin et al., 2008 and references therein). As a consequence, the mass fluxes here reported should not be regarded strictly as a "downward flux" but rather as the integration of a variety of sources including the settling flux from the water column, resuspension and rebounding (Walsh et al., 1988) from the seafloor, and advection of the bottom nepheloid layer by tides. The term 'apparent flux' rather than 'downward flux' is therefore used hereafter.

Mooring M1 included an Aanderaa current meter RCM-9 at 20 mab. Additional data from RCM-9 units deployed at 300 mab in line M1 were available discontinuously. An RCM-8 Aanderaa current meter was installed at 20 mab in Mooring M2 (Fig. 1). Together with current speed and direction, RCM units recorded pressure, temperature and conductivity. RCM-9s were also equipped with turbidimeters (optical back-scatter sensors), which were calibrated according to Guillén et al. (2000). Sampling interval of current meters/turbidimeters was set to $30 \mathrm{~min}$. 


\subsection{Processing and analysis of sediment trap samples}

Sediment trap samples were treated and subsampled following the procedures described in Heussner et al. (1990). Total mass flux (TMF) was calculated from the sample dry weight, the collecting area of the trap and the sampling interval. Total carbon and nitrogen were measured by high-temperature combustion and detection of the gaseous by-products in a LECO CN-2000 analyzer. For inorganic carbon the samples were decarbonated in a LECO CC-100 module coupled to the CN-2000 that consists of a stirred bath of $6 \mathrm{M} \mathrm{HCl}$ (digestion time $=1 \mathrm{~min}$ ). The released $\mathrm{CO}_{2}$ was analyzed by the CN-2000 and the inorganic carbon content of the sample back-calculated. Calcium carbonate content was then obtained from inorganic carbon using the molecular mass ratio 8.33 , assuming that all inorganic carbon was in the form of calcium carbonate. Organic matter was assumed to be twice the organic carbon content (calculated as the difference between total and inorganic carbon). Biogenic silica was analyzed using a wet-alkaline extraction with $\mathrm{Na}_{2} \mathrm{CO}_{3}$ following the method by Mortlock and Froelich (1989). The lithogenic fraction was then calculated as the residue of the sample after discounting the contents of biogenic silica, carbonates and organic matter.

Grain-size analysis of sediment trap samples was performed after disaggregation and removal of the biogenic fraction with $\mathrm{H}_{2} \mathrm{O}_{2}(10 \% \mathrm{v} / \mathrm{v})$ and dispersed using an ultrasonic bath. The grain-size distribution was measured using a laser forward-scattering particle sizer (MALVERN MicroP 2000). Bulk mineralogy of the samples was analyzed by XRay diffraction $(\mathrm{XRD})$ in non-oriented powders $(<63 \mu \mathrm{m}$ fraction). The scans were run between 2 and $60^{\circ} 2 \theta$ in a PANalytical diffractometer using $\mathrm{CuK} \alpha$ radiation. For semi- 
quantitative determination, the criteria recommended by Schultz (1964), Thorez (1976), and Rocha (1993) and retaken by Oliveira et al. (2007) have been followed.

${ }^{210} \mathrm{~Pb}$ concentration of sediment trap samples was measured via its alpha-particle emitting granddaughter isotope ${ }^{210} \mathrm{Po}$, assuming secular equilibrium between ${ }^{210} \mathrm{~Pb}$ and

${ }^{210}$ Po. Aliquots of dried and ground trap samples were spiked with ${ }^{209} \mathrm{Po}$ as a yield tracer and then totally digested in a cocktail of $\mathrm{HNO}_{3}$ and HF. After removal of the acids by evaporation, the polonium isotopes were collected by spontaneous deposition on a silver disc and counted with a Passivated Implanted Planar Silicon (PIPS) Canberra detector.

\subsection{Oceanographic and hydrographical data}

Wave data were obtained from an oceanographic buoy maintained by Puertos del Estado (Ministerio de Fomento, Spain) at Silleiro $\left(43^{\circ} 29.4^{\prime} \mathrm{N}, 9^{\circ} 12.6^{\prime} \mathrm{W} ; 386 \mathrm{~m}\right.$ bottom depth). Although this buoy is $200 \mathrm{~km}$ north from the study area, its records are considered representative of the storms that strike the Iberian Atlantic coast. Additional wave data was obtained from the forecast model Wavewatch III. Monthly discharge of Portuguese rivers was obtained from "Sistema Nacional de Informação de Recursos Hidricos" (Ministerio do Ambente, Portugal). 


\section{Results}

Time series of mass flux, major constituents, grain size and mineralogy of sediment trap samples collected at mooring locations $\mathrm{T} 1$ and $\mathrm{T} 2$, respectively, are presented in figures 2 and 3.

\subsection{Bulk mass fluxes}

\subsubsection{T1 ( 1600 m depth)}

Although we expected strong active sediment movement in the Nazaré Canyon on the basis of its impressive topography and previously published papers, nonetheless we had underestimated the magnitude of the particle fluxes to be encountered. Sediment trap T1 was overfilled soon after it was put in operation in October 2002, yielding a minimum mass flux of $73.2 \mathrm{~g} \mathrm{~m}^{-2} \mathrm{~d}^{-1}$. Expecting weaker particle fluxes during spring-summer, the trap was installed again at the same height above the bottom ( $25 \mathrm{mab})$ in the second deployment starting on April 2003. To our surprise, the trap was again overfilled before finishing its second sampling period, measuring a (minimum) mass flux of $81.3 \mathrm{~g} \mathrm{~m}^{-2} \mathrm{~d}^{-}$ 1. To overcome these problems, the trap was lifted from 25 to 50 mab in subsequent deployments. A technical failure prevented the trap from sampling during the third deployment period, but it performed satisfactorily during the fourth and fifth deployments. A range of mass flux from 6.8 to $14.6 \mathrm{~g} \mathrm{~m}^{-2} \mathrm{~d}^{-1}$ (mean value $10.3 \mathrm{~g} \mathrm{~m}^{-2} \mathrm{~d}^{-1}$ ) was measured during the fourth deployment, corresponding to spring-summer 2004. In the fifth deployment (November-December 2004), traps were programmed with higher resolution (5 days interval), in an attempt to catch a glimpse of winter sedimentary 
dynamics while preventing premature interruptions of the sampling. Fluxes during this last deployment period were notably high, ranging from 30 to more than $250 \mathrm{~g} \mathrm{~m}^{-2} \mathrm{~d}^{-1}$.

\subsubsection{T2 ( 3300 m depth)}

Mass fluxes at the deepest site were in general lower than at $\mathrm{T} 1$ and below $10 \mathrm{~g} \mathrm{~m}^{-2} \mathrm{~d}^{-1}$ during $75 \%$ of the total sampled time. Episodes of sharp increase in particle flux were also recorded at T2 and in two occasions (January and October-November 2003) led to trap overfilling (Fig. 3). The minimum mass fluxes recorded during these two extreme events were 137.4 and $83.9 \mathrm{~g} \mathrm{~m}^{-2} \mathrm{~d}^{-1}$ respectively. Excluding extreme flux values $>50 \mathrm{~g}$ $\mathrm{m}^{-2} \mathrm{~d}^{-1}$, mean settling fluxes were 7.7, 8.2, 4.3 and $4.1 \mathrm{~g} \mathrm{~m}^{-2} \mathrm{~d}^{-1}$ for the deployments I II, IV and V respectively.

\subsection{Particulate matter composition}

The relative concentrations of the main particulate matter components were fairly homogeneous at both sampling sites over time (Figs. 2 and 3) and thus no seasonal trends were identifiable in the composition of the material collected. The lithogenic fraction dominated the composition, accounting for $\sim 84 \%$ and $\sim 82 \%$ of the total flux in traps T1 and T2 respectively. Organic matter content of the samples was most of the time below 5\% and always below $6 \%$. The time-weighted mean organic matter content was remarkably similar at both traps and equal to $4.2 \%$. It must be noted that organic contents could have been underestimated since all non-disaggregable particles with size $>1 \mathrm{~mm}$ were routinely removed from sediment trap samples before organic carbon was analysed. Organic matter included fragments of coalified wood, as well as plant material 
(apparently fragments of eelgrass blades) which were relatively abundant in trap samples, particularly in the first overfilled sample of trap T2 (January 2003, Fig. 3). The organic matter present in the analyzed samples had a clear refractory and/or terrigenous imprint as indicated by the high $\mathrm{OC} / \mathrm{N}$ (atomic) ratios, which ranged from 11.8 to 20.9 at site $\mathrm{T} 1$ and from 11.3 to 20.7 at $\mathrm{T} 2$. Carbonate contents were remarkably stable in the ranges of $8.7-11.2 \%$ and $8.8-15.1 \%$ for $\mathrm{T} 1$ and $\mathrm{T} 2$ respectively. Biogenic silica contents were very low during all the deployments at both depths, and in fact close to the reliability limit ( $\sim 3 \%)$ of the analytical method (Mortlock and Froelich, 1989).

\section{3. ${ }^{210} \mathrm{~Pb}$ concentration in settling particles}

${ }^{210} \mathrm{~Pb}$ total concentrations of sediment trap samples are available for deployments I-IV and shown in Figs. 2 and 3 for traps T1 and T2 respectively. A relatively narrow range of ${ }^{210} \mathrm{~Pb}$ concentrations $\left(479-713 \mathrm{~Bq} \mathrm{~kg}^{-1}\right.$ ) was found at $\mathrm{T} 1$ (weighed mean $=615 \mathrm{~Bq} \mathrm{~kg}^{-}$ ${ }^{1}$ ). At $\mathrm{T} 2,{ }^{210} \mathrm{~Pb}$ concentrations ranged from 290 to $1768 \mathrm{~Bq} \mathrm{~kg}^{-1}$ (weighed mean 1021 $\left.\mathrm{mBq} \mathrm{g}^{-1}\right)$. While ${ }^{210} \mathrm{~Pb}$ at the shallower trap $\mathrm{T} 1$ is rather stable with increasing mass flux, at T2 it exhibits a clear decreasing trend that can be adjusted to a power fit (Fig. 4). For settling fluxes below $5 \mathrm{~g} \mathrm{~m}^{-2} \mathrm{~d}^{-1},{ }^{210} \mathrm{~Pb}$ concentrations at $\mathrm{T} 2$ were higher than $1200 \mathrm{~Bq}$ $\mathrm{kg}^{-1}$. Taking into account that total activity of ${ }^{210} \mathrm{~Pb}$ in surface sediments of the Nazaré Canyon ranges between 200-1200 $\mathrm{Bq} \mathrm{kg}^{-1}$ (De Stigter et al., 2007), values above 1200 $\mathrm{Bq} \mathrm{kg}^{-1}$ suggest a contribution of ${ }^{210} \mathrm{~Pb}$ produced in the overlying water column from dissolved ${ }^{226} \mathrm{Ra}$. On the contrary, for mass fluxes higher than $5 \mathrm{~g} \mathrm{~m}^{-2} \mathrm{~d}^{-1},{ }^{210} \mathrm{~Pb}$ concentrations at T2 decline rapidly with increasing mass to a rather stable value $\sim 600$ $\mathrm{Bq} \mathrm{kg}^{-1}$, similar to the values typical of the shallower trap $\mathrm{T} 1$ and indicative of resuspended or reworked old sediments (Fig. 4). There is a potential overestimation of 
${ }^{210} \mathrm{~Pb}$ concentration in the samples from autumn 2004 , given that only three ${ }^{210} \mathrm{Po}$ halflives had passed between sampling and analysis. Being a weak beta emitter, the radionuclide ${ }^{210} \mathrm{~Pb}$ is usually measured by analysis of its gamma-emission or indirectly by alpha-counting its grand-daughter radionuclide ${ }^{210} \mathrm{Po}$. The last approach, used in this study, is valid as long as secular equilibrium between ${ }^{210} \mathrm{~Pb}$ and ${ }^{210} \mathrm{Po}$ has been reached. However, it seems that excess ${ }^{210} \mathrm{Po}$ does not pose an important bias to the measurements, based on the fact that ${ }^{210} \mathrm{~Pb}$ concentrations measured in October 2002 (in secular equilibrium with ${ }^{210} \mathrm{Po}$ ), were similar to those measured in Autumn 2004 (see Figs. 2 and 3), under similar mass flux.

\subsection{Mineralogy and granulometry of sediment trap samples}

Mineralogy and grain size data are available for deployments I to IV (Figs. 2 and 3). Silt and clayey silt dominated the grain size distribution of sediment trap samples at both depths throughout the study, although sandy silt and silty sands were also apparent during certain periods. The sandiest sample (35\% sand) was collected in January 2003 during the overfilling of trap $\mathrm{T} 2$. The fine sediment fraction mineralogy was rather monotonous with the same mineral types recorded during the four useful mooring deployment periods. The particles collected by the sediment traps showed higher mica/illite contents (mean 22\%) and lower calcite contents (including calcite $\mathrm{Mg}$ ), quartz and feldspars than bottom samples collected at nearby locations (Oliveira et al., 2007). There is a clear relationship between the mineralogy of the sediment trap samples and that of shelf sediments, although with increased importance of phyllosilicate minerals, as also found in suspended particulate matter near the seafloor (Oliveira et al., 2007). 


\subsection{Mean near-bottom currents}

Time-series of 30 minute-averaged near-bottom currents (rotated to fit the approximate direction of the canyon axis at each location) and temperature during two periods representative of calm conditions (i.e. in the absence of stormy weather or gravity flows) at the two mooring sites are shown in figure 5. At M1, this figure also shows suspended sediment concentration (SSC). The physical environment at the site M1 is characterized by strong tidal oscillations resulting in instantaneous current speeds up to $80 \mathrm{~cm} \mathrm{~s}^{-1}$ during spring tides. Near-bottom tides were weaker at M2, with instantaneous current speeds up to $32 \mathrm{~cm} \mathrm{~s}^{-1}$. Over the entire studied period, current speeds averaged $22.9 \mathrm{~cm} \mathrm{~s}^{-1}$ and $7.7 \mathrm{~cm} \mathrm{~s}^{-1}$ at M1 and M2 respectively.

\subsection{Episodes of down-canyon sediment transport associated to shelf storms}

\subsubsection{Winter 2002-2003}

Time-series of wave parameters, near-bottom hydrology, turbidity, current speed and sediment trap data were collected from December 2002 to February 2003 at both sites, in addition to turbidity at 20 and 300 mab in mooring M1 (Fig. 6).

Several storms with significant wave heights $\left(\mathrm{H}_{\mathrm{s}}\right)$ from 4 to more than $8 \mathrm{~m}$ affected the continental shelf from December 2002 to February 2003. The impact of these storms at M1 can be analyzed only from the current-meter/turbidimeter data, since the sediment trap was already overfilled before this stormy period. Four consecutive marked increases in turbidity were registered near the bottom at M1 (Fig. 6). These high- 
turbidity events increased SSC near the bottom and $300 \mathrm{~m}$ above bottom and were also associated with temperature increases and some salinity decrease (Fig. 6). The nearbottom turbidity sensor (range 0-20 NTU) went off scale in each of these four episodes. The trend of low-pass filtered temperature at M1 (Fig. 6) mimics that of turbidity increasing during the four high-turbidity events. Two of these four turbidity increases coincided with storms with $\mathrm{H}_{\mathrm{s}}>6 \mathrm{~m}$, while the relationship is not so clear in the other two episodes. However, during the two events associated with major shelf storms (late December 2002 and late January 2003), the settling flux of the deepest trap (T2) increased very notably, suggesting a link between the continental shelf and the distal middle canyon under severe stormy conditions. Special attention merits the third turbid event (January 2003) corresponding to the most dramatic storm of that winter $\left(\mathrm{H}_{\mathrm{s}}\right.$ up to $8.5 \mathrm{~m})$. A marked increase of the mass flux was noticed at T2 (3200 m depth) during that episode, to the point of overfilling the trap. Before it became inoperative, the trap had collected a mass equivalent to a flux of $137 \mathrm{~g} \mathrm{~m}^{-2} \mathrm{~d}^{-1}$. Both the quantity and characteristics of the trapped particles were remarkable since the overfilled sample was the sandiest of all sampled material ( $35 \%$ of bulk sample $>62.5 \mu \mathrm{m})$ and vegetal debris (mainly wood chunks and fragments of leaves from vascular plants) were also notably more abundant than the average. On March 11 2003, another gravity flow was detected at a location close to M2 (De Stigter et al., 2007) concomitant with a storm with $\mathrm{H}_{\mathrm{s}}>8 \mathrm{~m}$ (data not shown).

\subsubsection{Autumn-winter 2003}

Time-series of wave parameters and selected variables collected during the stormy period of autumn-winter 2003 are shown in figure 7. Particle flux and current data were 
available only for the deepest M2 site and turbidity data at midwaters only from the end of November. Trap M2 overfilled in coincidence with a storm with $\mathrm{H}_{\mathrm{s}}$ close to $9 \mathrm{~m}$ that struck the Iberian Atlantic Margin between 30 October and 2 November. Unlike the previous winter, the current meter data did not suggest a sediment gravity flow (Fig. 7) and the grain size of the material that overfilled the trap was remarkably finer than in the case of January 2003. The high mass flux observed during the first trap sample interval before the storm is attributed to resuspension caused by the mooring hitting the seafloor, as observed in other occasions. Two increases of SSC were observed at midand late-December 2003 in midwaters (Fig. 7), in connection to relatively weak increases of wave energy. In particular, a storm during late-December with $\mathrm{H}_{\mathrm{s}}$ around 5 m was apparently associated to both SSC enhancement at midwaters in the upper canyon and an increase of the down-canyon current speed at $3300 \mathrm{~m}$. This event was simultaneously detected by another sediment trap deployed at $4300 \mathrm{~m}$ depth and identified as a gravity flow (De Stigter et al., 2007; Fig. 7).

\subsubsection{Autumn-Winter 2004}

Time-series of wave parameters and particle flux measured during October-December 2004 are presented in Fig. 8. Current and water turbidity data were not available for this period. The high resolution (5 days) of sediment trap sampling during this deployment allowed observation of particle fluxes at $\mathrm{T} 1$ under relatively energetic conditions while preventing rapid overfilling the trap. In fact, the effect of at least two storms at $\mathrm{T} 1 \mathrm{can}$ in this case be discerned from the background of very high particle fluxes derived from tidal resuspension and the bottom nepheloid layer. The time series show three consecutive events of high particle flux at T1 (approximately 10-19 November; 1-10 
December and 19-29 December) and at least on two occasions they seemed connected to increases in wave energy over the continental shelf. The first event (first half of November) was characterized by mass fluxes around $170 \mathrm{~g} \mathrm{~m}^{-2} \mathrm{~d}^{-1}$ and relatively weak $\mathrm{H}_{\mathrm{s}}$ up to $4 \mathrm{~m}$. The second event showed higher mass fluxes (up to $210 \mathrm{~g} \mathrm{~m}^{-2} \mathrm{~d}^{-1}$ ) and correlative $\mathrm{H}_{\mathrm{s}}$ surpassing $5 \mathrm{~m}$. During the third event, the sediment trap overfilled (minimum mass flux $265 \mathrm{~g} \mathrm{~m}^{-2} \mathrm{~d}^{-1}$ ) in coincidence with a storm with $\mathrm{H}_{\mathrm{s}}$ of $6 \mathrm{~m}$. It is worth noting that none of the flux increases at $1600 \mathrm{~m}$ were observed simultaneously at $3200 \mathrm{~m}$ depth, and that a storm with $\mathrm{H}_{\mathrm{s}}$ close to $7 \mathrm{~m}$ during late December also had no discernible effect at this depth (Fig. 8).

\section{Discussion}

\subsection{Sedimentary conditions at the upper and middle canyon sites}

\subsubsection{Site M1 (upper canyon; $1500-1600$ m depth)}

The extremely high apparent fluxes measured by the near-bottom trap at M1 testify to the intense sedimentary activity taking place in this part of the canyon. The middle Nazaré Canyon at 1500-1600 is characterized by permanent conditions of very high current speed (Fig. 5). Under these conditions, fine unconsolidated sediments are continuously resuspended by tidal currents (De Stigter et al., 2007). Apart from tidal currents, other processes may contribute to enhanced particle resuspension and transport in the middle canyon. Significant internal wave formation, as well as bottom-intensified tides have been identified between the MW lower limit and the canyon bed (Vitorino et al., 2005). Oceanographic cruises conducted during 2002 and 2004 repeatedly found maxima of turbidity at the upper $(500-800 \mathrm{~m})$ and lower $(1100-1400 \mathrm{~m})$ limits of the 
MW core (Oliveira et al., 2007). In particular, a very turbid and recurrent bottom nepheloid layer has been observed between 1200 and $1400 \mathrm{~m}$ depth, at the approximate lower contact of the Mediterranean water with the seafloor (De Stigter et al., 2007). Also, the stable and low values of ${ }^{210} \mathrm{~Pb}$ at $\mathrm{M} 1$ (close to the activity of surface sediments) reinforces the idea that this part of the canyon is subject to permanent high fluxes from a dominant homogeneous source, consisting of sediments resuspended from the adjacent shelf and transported into the canyon where they may undergo many resuspension/redeposition cycles until all excess ${ }^{210} \mathrm{~Pb}$ is depleted.

\subsubsection{Site M2 (middle canyon; $3200-3300$ m depth)}

Time series of mass fluxes at M2 ( 3300 m depth) were longer than at M1 and were not affected by high current speeds. Mass fluxes were in general lower at this site, although the particle composition was remarkably homogeneous between both stations, suggesting a common origin of the bulk flux (Heussner et al., 2006).

Two contrasting situations can be distinguished in the annual dynamics of apparent mass flux at M2: during spring-summer, fluxes are relatively steady and lower than $8 \mathrm{~g}$ $\mathrm{m}^{-2} \mathrm{~d}^{-1}$; in autumn-winter, total fluxes are notably higher as a consequence of sharp flux increase events up to more than $130 \mathrm{~g} \mathrm{~m}^{-2} \mathrm{~d}^{-1}$. To account for the sediment accumulation

rates of 8-33 $\mathrm{g} \mathrm{m}^{-2} \mathrm{~d}^{-1}$ obtained at similar depths (De Stigter et al., 2007), and taking into account that trap fluxes are probably overestimated, it must be acknowledged that pulsed inputs of sediment, rather than steady sedimentation, make up the bulk of the sediment accretion in the middle canyon. 


\subsection{Storms as drivers of pulsed sediment transport through the canyon}

Increases of SSC both near the bottom and at intermediate waters at M1 (upper canyon) were simultaneous to storms with $\mathrm{H}_{\mathrm{s}}$ between 4 and $6 \mathrm{~m}$. This suggests either the formation of bottom nepheloid layers (BNL) hundreds of meters thick or detachments of intermediate nepheloid layers together with discrete BNLs. Major storms with $\mathrm{H}_{\mathrm{s}}$ above $7 \mathrm{~m}$ occurred in January and October 2003 and correspond to strong increases in particle flux in the middle canyon to the point of overfilling trap M2. However, the effects of these two major storms at M2 differed both in the transport mechanisms and the properties of the particles involved. In January 2003, a gravity flow was observed at the deepest site carrying relatively coarse particles. During the overfilling of the trap at M2 an increase of down-canyon near-bottom current speed occurred simultaneously with an increase of near-bottom temperature and a decrease of salinity (Fig. 6). Similar signatures have been observed for the passage of sediment gravity flows (Palanques et al., 2006b; Khripounoff et al., 2009). At M1, SSC and temperature also increased and salinity decreased simultaneously with overfilling of the deepest trap at M2. However, no related increase of current speed was observed at M1, and therefore the gravity flow observed at $\mathrm{T} 2$ had to originate in an intermediate location down-canyon from $\mathrm{T} 1$, but ultimately related to the enhancement of sediment transport observed at $\mathrm{T} 1$ during the January storm. In fact, $\mathrm{T} 1$ is located just up-canyon from the area of maximum bathymetric gradient of the canyon axis (Vanney and Mougenot, 1993), which is therefore a good candidate as an area in which gravity flows might be generated. In addition, nepheloid layers advancing offshore from the upper course along the middle canyon could have also contributed to the downward particle flux increases at T2. 
Unlike the storm of January 2003, the October 2003 storm (Fig. 7) was not accompanied by an increase of the near-bottom residual current and temperature at M2. Furthermore, sand and plant debris were present in much smaller amounts. This suggests that in this case, the trap was filled as a consequence only of nepheloid layers generated by the storm, without the interplay of near-bottom gravity transport. The major autumn storm could have generated a turbidity current that did not reach M2, but generated bottom and intermediate nepheloid layers that impacted this deep site. It has been observed in the past that bottom nepheloid layers at the canyon head extend into the upper and middle canyon as intermediate nepheloid layers (Van Weering et al., 2002). The strong changes in slope along the canyon axis likely favour the detachment of these turbid layers.

As shown in Fig. 7, storms with $\mathrm{H}_{\mathrm{s}}$ as low as $5 \mathrm{~m}$ are apparently able to trigger density currents that traverse the entire middle canyon. Although shelf storms clearly have an impact on deep fluxes in the canyon, wave height alone cannot justify the intense downcanyon transport events observed, and other concurrent or modulating factors must be invoked.

\subsection{Role of river discharge on sediment flows in the canyon?}

Although the Nazaré Canyon is usually considered unconnected to fluvial systems, the potential nourishment of the canyon head with sediments delivered by rivers discharging north from the canyon should not be neglected, taking into account the fact that the mean sedimentary drift is markedly southward. Additionally, the contribution of several small (but undammed) streams southwards from Nazaré has been signalled as a 
probable source of sediments to the shelf and the canyon mouth in winter (Oliveira et al., 2007). In particular, the Mondego River has a watershed of $6644 \mathrm{~km}^{2}$ and opens to the sea about $50 \mathrm{~km}$ north of the canyon head. In spite of considerable regulation of the Mondego flow, substantial flooding still occurs (up to $1900 \mathrm{~m}^{3} \mathrm{~s}^{-1}$ measured at Coimbra in January 2001; Proença Cunha, 2003). Monthly discharge of the Mondego and Agueda (tributary to the Vouga, which opens to the sea $100 \mathrm{~km}$ north of the canyon head) rivers during the study period are shown in figure 9. Unusually heavy rainfall and river flow rates were registered in the Atlantic side of the Iberian Peninsula both in December 2002 and January 2003 (Rodrigues et al., 2003; Fig. 9), corresponding to the two major mass flux pulses in trap T2 (Fig. 6). In particular, the overfilling of the trap coincided with the period of maximum river discharge, more than five times higher than the interannual mean (1990-2009) for the month of January (Fig. 9). This suggests that storms are able to trigger sediment transport events that reach the deep mooring site at the end of the rainy season, following the accumulation of sufficient material on the shelf. Also at $4200 \mathrm{~m}$ depth (Fig. 7) an important increase of the mass flux occurred in December-January 2003 just after the peak of the rainy period (Fig. 9). Furthermore, during the relatively dry winter of 2004, the effect of storms was documented at M1 but did not reach M2 even when $\mathrm{H}_{\mathrm{s}}$ reached $\sim 7 \mathrm{~m}$ (Fig. 7). An exception to this rule is the storm of 30 October-1 November 2003, which enhanced sediment transport at M2 during the first rains of autumn, but it must be taken into account that this storm was the strongest recorded $\left(\mathrm{H}_{\mathrm{s}}\right.$ up to $\left.10.3 \mathrm{~m}\right)$. 


\subsection{Other factors potentially relevant in the triggering of deep sediment transport}

Since the Iberian Margin is seismically active (Alves et al., 2003), we also investigated the occurrence of earthquakes during the periods of operation of the sediment traps and their eventual impact on offshore sediment transport. The largest seismic events during the sampled period took place on July 292003 and December 142004 SW of Cape Sao Vicente with a similar intensity of 5.4 in the Richter scale (Carrilho, 2005). No effect of these earthquakes on sediment transport was discernable in our dataset.

More likely drivers for down-canyon sediment transport are downwelling at the canyon head and the associated enhancement of internal waves (Vitorino et al., 2002a,b). During winter, south and east winds promote downwelling over the Iberian Shelf, implying net offshore transport in the bottom Ekman layer (Vitorino et al., 2002a,b). It has been suggested that detaching of nepheloid layers from the upper canyon is favoured during downwelling conditions at the Nazaré Canyon head (Oliveira et al., 2007). As a consequence of downwelling in the canyon head, warm oceanic water is displaced towards the coast, thus enhancing the vertical density gradient and the scope for internal waves to develop (Vitorino et al., 2002a,b). Near the bottom, the density gradient is further enhanced by the presence of dense nepheloid layers, a process that may be amplified following wave-induced resuspension on the continental shelf and the subsequent transport of particles into the canyon. Hence, storms that are not able to trigger significant down-canyon transport directly may however favour far-reaching down-canyon density currents generated in synergy with downwelling conditions and internal waves. 


\subsection{Origin of particles trapped in the middle canyon}

Given the relative temporal and spatial homogeneity of the four main particle components (opal, carbonate, organic matter and lithogenics) during this study, it is difficult to discriminate between recent supply of shelf and coastal material and resuspension of past supply, accumulated temporarily on the canyon bed. Mica/illite percentage was higher and calcite, quartz and feldspars percentages lower in sediment trap samples than in bottom samples collected at nearby locations (Oliveira et al., 2007). This can be an indication of preferential transport in nepheloid layers, since suspended particulate matter show higher values of mica/illite $(>60 \%)$ than bottom samples (Oliveira et al., 2007). The $\mathrm{CaCO}_{3}$ contents of sediment trap samples were remarkably stable at both traps and close to those reported by Alt-Epping et al. (2007) in the continental shelf adjacent to the Nazaré canyon head (12-15\%), and by Van Weering et al. (2002) in surface sediments of the middle Nazaré Canyon (8-12\%). This uniformity reflects intense mixing of sediments during repeated episodes of resuspension, but it could also suggest that most of the particles reaching the upper and middle canyon have a common origin in a temporary reservoir near the canyon head, from where they are redistributed down-canyon, whether slowly by the action of tides and internal waves (Quaresma et al., 2007) or in fast pulses when gravity currents develop. An exception can be found in the overfilling of T2 trap in January 2003 when the minimum $\mathrm{CaCO}_{3}$ content of the time series ( $8 \%$, see Fig. 3) was found. This can indicate a shallower, coastal origin since Alt-Epping et al. (2007) reported $\mathrm{CaCO}_{3}$ contents of $12-15 \%$ in sediments adjacent to the Nazaré canyon head but only 5\% closer to the coast. During the rest of the study carbonates were rather stable at $13.2 \pm 1.6 \%$ in the deepest trap $\mathrm{T} 2$, suggesting contributions from the main sedimentary source in the shelf surrounding the canyon head. Concomitantly with the decrease of carbonate at T2 during the overfilling 
of January 2003, organic carbon decreased drastically whereas the sand fraction and terrigenous constituents such as quartz and dolomite increased. This could be indicative of coastal transport, although the increase of dolomite inside the canyon could also be an indication of a different source region, richer in dolomite, in the northern outer shelf (Oliveira et al., 2007).

OC/N ratios in sediment trap samples (range 11-30) were well in excess of both the Redfield ratio and the range 4-9 reported by Alt-Epping et al. (2007) in sediments of mainly marine origin on the continental shelf north of the canyon head. The high OC/N values of trap samples are indicative of terrestrial organic matter and/or old reworked sediments, where labile organic matter has been remineralized after successive resuspension-deposition cycles. The frequent presence of continental vegetal debris and wood chunks in the samples at both depths, and particularly during the extreme flux pulse of January 2003 at the deep mooring site, confirms the relevance of terrestrial inputs into the canyon.

\section{Summary}

The observation of near-bottom particle fluxes at $1600 \mathrm{~m}$ and $3300 \mathrm{~m}$ depth in the Nazaré submarine canyon has revealed some contrasting features. The shallowest site $(1600 \mathrm{~m})$ is an extremely dynamic environment with permanent conditions of high particle fluxes year-round. Seasonal variability of fluxes is more evident at the deepest site $(3300 \mathrm{~m})$, where periods of relatively low and steady mass flux in spring-summer and in the absence of major shelf storms are followed by a more variable regime during autumn-winter. In the latter case, sharp increases of the apparent particle flux occur 
related to shelf storms and overall govern the annually integrated mass flux. Storms impinging in the continental shelf enhanced sedimentary activity in the upper and middle canyon, causing apparent near-bottom fluxes exceeding $230 \mathrm{~g} \mathrm{~m}^{-2} \mathrm{~d}^{-1}$ at $1600 \mathrm{~m}$ in the upper canyon axis and $130 \mathrm{~g} \mathrm{~m}^{-2} \mathrm{~d}^{-1}$ at $3200 \mathrm{~m}$ depth in the middle canyon axis. In addition to, or more likely in synergy with the action of storms, flooding of rivers north of the canyon head apparently contributes to triggering the observed increases in particle flux to the middle canyon. The composition of trapped particles was rather uniform at both sites, and suggests an important terrigenous contribution.

\section{Acknowledgments}

We thank the officers and crew of the $\mathrm{R} / \mathrm{V}$ Auriga and $\mathrm{R} / \mathrm{V}$ Andromeda (Instituto Hidrográfico) for their help during the ship operations. We warmly acknowledge the work of João Caldas and the Instituto Hidrográfico staff for the technical, logistic and field efforts crystallized in this work. We thank Silvia de Diago for analytical work at ICM-CSIC. Two anonymous reviewers contributed to improve the original manuscript with their constructive criticism. J. Martín was funded during this study through a FPI scholarship granted by Ministerio de Ciencia y Tecnología (Spanish Ministry of Science and Technology), and by the EUROSTRATAFORM project (EKV3-CT-2002-00079). 


\section{References}

Alt-Epping, U., Mil-Homens, M., Hebbeln, D., Abrantes, F., Schneider, R.R., 2007. Provenance of organic matter and nutrient conditions on a river- and upwelling influenced shelf: A case study from the Portuguese Margin. Marine Geology 243, 169179.

Alves, T.M., Gawthorpe, R.L., Hunt, D.W., Monteiro, J.H., 2003. Cenozoic tectonosedimentary evolution of the western Iberian margin. Marine Geology 195, 75-108.

Bonnin, J., Heussner, S., Calafat, A., Fabres, J., Palanques, A., Durrieu de Madron, X., Canals, M., Puig, P., Avril, J., Delsaut, N., 2008. Comparison of horizontal and downward particle fluxes across canyons of the Gulf of Lions (NW Mediterranean): Meteorological and hydrodynamical forcing. Continental Shelf Research 28, 19571970.

Canals, M., Puig, P., Heussner, S., Durrieu de Madron, X., Palanques, A., Fabres, J., 2006. Flushing submarine canyons. Nature, 444, 354-357.

Carrilho, J., 2005. Estudo da sismicidade da Zona Sudoeste de Portugal Continental, M.S. thesis. University of Lisboa, $172 \mathrm{pp.}$

De Stigter, H.C., Boer, W., Jesus Mendes, P.A., Jesus C.C., Thomsen, L., van den Bergh, G.D., Van Weering, T.C.E., 2007. Recent sediment transport and deposition in Nazaré Canyon, Portuguese continental margin. Marine Geology 246(2-4), 144-164. 
Drago, T., Oliveira, A., Magalhães, F., Cascalho, J., Jouanneau, J.-M., Vitorino, J., 1998. Some evidences of northward fine sediment transport in the northern Portuguese continental shelf. Oceanologica Acta 21(2), 223-231.

Fiúza, A.F.G, Macedo, M.E., Guerreiro, M.R., 1982. Climatological space and time variation of the Portuguese coastal upwelling. Oceanologica Acta 5(1), 31-40.

Frouin, R., Fiúza, A.F.G., Ambar, I., Boyd, T. J., 1990. Observations of a poleward surface current off the coasts of Portugal and Spain during winter. Journal of Geophysical Research 95(C1), 679-691.

Guillén, J., Palanques, A., Puig, P., Durrieu de Madron, X., Nyffeler, F., 2000. Field calibration of optical sensors for measuring suspended sediment concentration in the western Mediterranean. Scientia Marina 64(4), 427-435.

Heussner, S., Ratti, C., Carbonne, J., 1990. The PPS 3 time-series sediment trap and the trap sample processing techniques used during the ECOMARGE experiment. Continental Shelf Research 10, 943-958.

Heussner, S., Durrieu de Madron, X., Calafat, A., Canals, M., Carbonne, J., Delsaut, N., Saragoni, G., 2006. Spatial and temporal variability of downward particle fluxes on a continental slope: lessons from an 8-yr experiment in the Gulf of Lions (NW Mediterranean). Marine Geology 234(1-4), 63-92. 
Hickey, B., Baker, E.T., Kachel, M., 1986. Suspended particle movement in and around Quinault submarine canyon. Marine Geology 71, 35-83.

Khripounoff, A., Vangriesheim, A., Babonneau, N., Crassous, P., Dennielou, B., Savoye, B., 2003. Direct observation of intense turbidity current activity in the Zaire submarine valley at $4000 \mathrm{~m}$ water depth. Marine Geology 194, 151-158.

Khripounoff, A., Vangriesheim, A., Crassous, P., Etoubleau, J., 2009. High frequency of sediment gravity flow events in the Var submarine canyon (Mediterranean Sea). Marine Geology 263(1-4), 1-6.

Lastras, G., Arzola, R.G., Masson, D.G., Wynn, R.B., Huvenne, V.A.I., Huhnerbach, V., Canals, M. 2009. Geomorphology and sedimentary features in the Central Portuguese submarine canyons, Western Iberian margin. Geomorphology, 103(3): 310329.

Lewis, K.B., Barnes, P.M., 1999. Kaikoura Canyon, New Zealand: active conduit from near-shore sediment zones to trench-axis channel. Marine Geology 162, 39-69.

Martín, J., Palanques, A., Puig, P., 2006. Composition and variability of downward particulate matter fluxes in the Palamós submarine canyon (NW Mediterranean). Journal of Marine Systems 60, 75-97. 
Martín, J., Palanques, A., Puig, P., 2007. Horizontal transfer of suspended particulate matter in the Palamós submarine canyon. Journal of Marine Research 65(2), 193218.

Martín, J., Puig, P., Palanques, A., Masqué, P., García-Orellana, J., 2008. Effect of commercial trawling on the deep sedimentation in a Mediterranean submarine canyon. Marine Geology 252(3-4), 150-155.

Masson, D.G., Huvenne, V.A.I., de Stigter, H.C., Arzola, R.G., Le Bas, T.P. 2011. Sedimentary processes in the middle Nazaré Canyon: the importance of small-scale heterogeneity in defining the large-scale canyon environment. Deep-Sea Research II (this issue).

McCave, I.N., Hall, I.R., 2002. Turbidity of waters over the Northwest Iberian continental margin. Progress in Oceanography 52, 299-313.

Mortlock, R.A., Froelich, P.N., 1989. A simple method for the rapid determination of biogenic opal in pelagic marine sediments. Deep-Sea Research A 36(9), 1415-1426.

Mulder, T., Weber, O., Anschutz, P., Jorissen, F.J., Jouanneau, J.M., 2001. A few months-old storm generated turbidite deposited in the Capbreton Canyon (Bay of Biscay, SW France). Geo-Marine Letters 21, 149-156. 
Oliveira, A., Santos, A.I., Rodrigues, A., Vitorino, J., 2007. Sedimentary particle distribution and dynamics on the Nazaré canyon system and adjacent shelf (Portugal). Marine Geology 246(2-4), 105-122.

Palanques, A., Durrieu de Madron, X., Puig, P., Fabrés, J., Guillén, J., Calafat, A., Canals, M., Heussner, S., Bonnin, J., 2006a. Suspended sediment fluxes and transport processes in the Gulf of Lions submarine canyons. The role of storms and dense water cascading. Marine Geology 234(1-4), 43-61.

Palanques, A., Martín, J., Puig, P., Guillén, J., Companys, J.B., Sardà, F., $2006 b$. Evidence of sediment gravity flows induced by trawling in the Palamós (Fonera) submarine canyon (northwestern Mediterranean). Deep-Sea Research I 53, 201-214.

Pfannkuche, O., 1993. Benthic response to the sedimentation of particulate organic matter at the BIOTRANS station, 47 N, 20 W. Deep-Sea Research II 40, 135-149.

Proença Cunha, P., 2003. Riscos associados com cheias fluviais. A.P.G. - Seminário “Riscos Geológicos”, 29-30 September 2003.

Puig, P., Palanques, A., 1998. Temporal Variability and composition of settling particle fluxes on the Barcelona continental margin (Northwestern Mediterranean). Journal of Marine Research 56, 639-654. 
Puig, P., Palanques, A., Sanchez-Cabeza, J.A., Masqué, P., 1999. Heavy metals in particulate matter and sediments in the southern Barcelona sedimentation system (North-western Mediterranean). Marine Chemistry 63(3-4), 311-329.

Quaresma, L.S., Vitorino, J., Oliveira, A., da Silva, J., 2007. Evidence of sediment resuspension by nonlinear internal waves on the western Portuguese mid-shelf. Marine Geology 246(2-4), 123-143.

Rocha, F., 1993. Argilas Aplicadas a Estudos Litoestratigráficos e Paleoambientais na Bacia Sedimentar de Aveiro. PhD Thesis, Aveiro University, 399 pp.

Rodrigues, R., Brandao, C., Pinto da Costa, J., 2003. As cheias do Douro, hoje, ontem e amanha. Instituto da Agua, Fevereiro 2003.

Schmidt, S., De Stigter, H.C., Van Weering, T.C.E., 2001. Enhanced short-term sediment deposition within the Nazaré Canyon, North-East Atlantic. Marine Geology $173,55-67$.

Schultz, L.G., 1964. Quantitative interpretation of mineralogical composition from Xray and Chemical data for the Pierre shale. US Geolical Survey Professional Paper 391C, 1-31.

Thorez, J., 1976. Practical identification of clay minerals. In: . Lelotte, G. (Ed.), A handbook for teachers and students in clay mineralogy. Dison, Belgique. 99 pp. 
Van Aken, H.M., 2000. The hydrography of the mid-latitude Northeast Atlantic Ocean.

II: The intermediate water masses. Deep-Sea Research I 47, 789-824.

Van Der Zee, C., Slomp, C.P., Van Raaphorst, W., 2002. Authigenic P formation and reactive $\mathrm{P}$ burial in sediments of the Nazaré canyon on the Iberian margin (NE Atlantic). Marine Geology 185, 379-392.

Van Weering, T.C.E., De Stigter, H.C., Boer, W., de Haas, H., 2002. Recent sediment transport and accumulation on the NW Iberian margin. Progress in Oceanography 52, 349-371.

Vanney, J.R., Mougenot, D., 1993. Un canyon sous-marin du type "gouf”: le Canhão da Nazaré (Portugal). Oceanologica Acta 13, 1-14.

Vitorino, J., Oliveira, A., Jouanneau, J.M., Drago, T., 2002a. Winter dynamics on the northern Portuguese shelf. Part 1: physical processes. Progress in Oceanography 52, 129-153.

Vitorino, J., Oliveira, A., Jouanneau, J.-M., Drago, T., 2002b. Winter dynamics on the northern Portuguese shelf. Part 2: bottom boundary layers and sediment dispersal. Progress in Oceanography 52, 155-170.

Vitorino, J., Oliveira, A., Beja, J., 2005. Physical processes in the Nazaré Canyon area and related sedimentary impacts. Geophysical Research Abstracts 7, 10187. 
Walsh, I., Fischer, K., Murray, D., Dymond, J., 1988. Evidence for resuspension of rebound particles from near-bottom sediment traps. Deep-Sea Research 35, 59-70.

Walsh, J.P., Nittrouer, C.A., 2003. Contrasting styles of off-shelf sediment accumulation in New Guinea. Marine Geology 196, 105-125.

Wooster, W., Bahun A., Mclain, D., 1976. The seasonal upwelling cycle along the eastern boundary of the North Atlantic. Journal of Marine Research 34(2), 131-141.

Xu, J.P., Noble, M.A., Rosenfeld, L.K., 2004. In-situ measurements of velocity structure within turbidity currents. Geophysical Research Letters 31(9), L09311. 


\section{Figure 1}

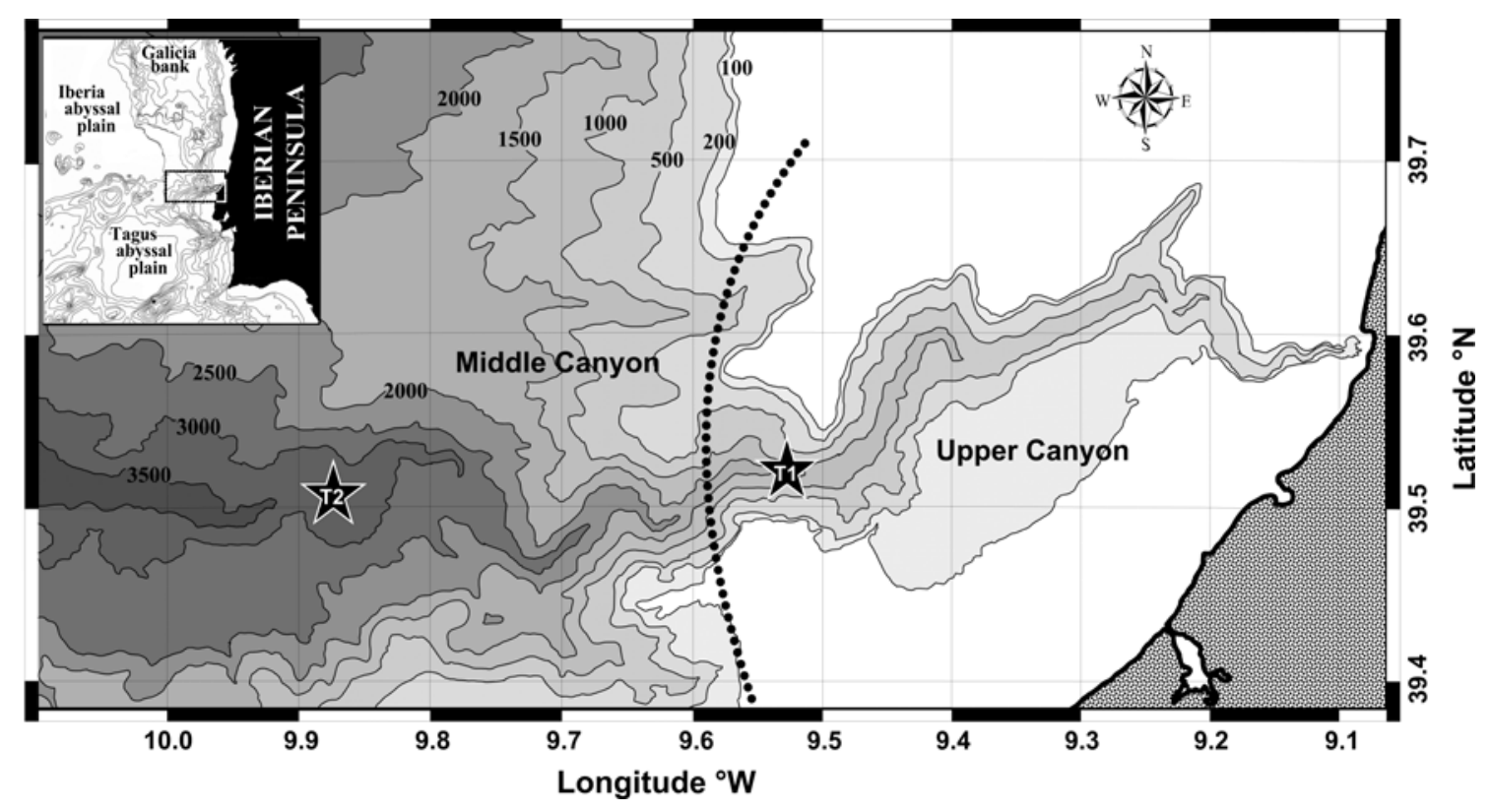

Fig. 1. Bathymetric chart of the Nazaré submarine canyon (modified after Vanney and Mougenot, 1993) and positions of the two moorings (stars). Each mooring carried a near-bottom PPS3/3 sediment trap coupled to a current meter (see text and Table 1 for details). 
Figure 2
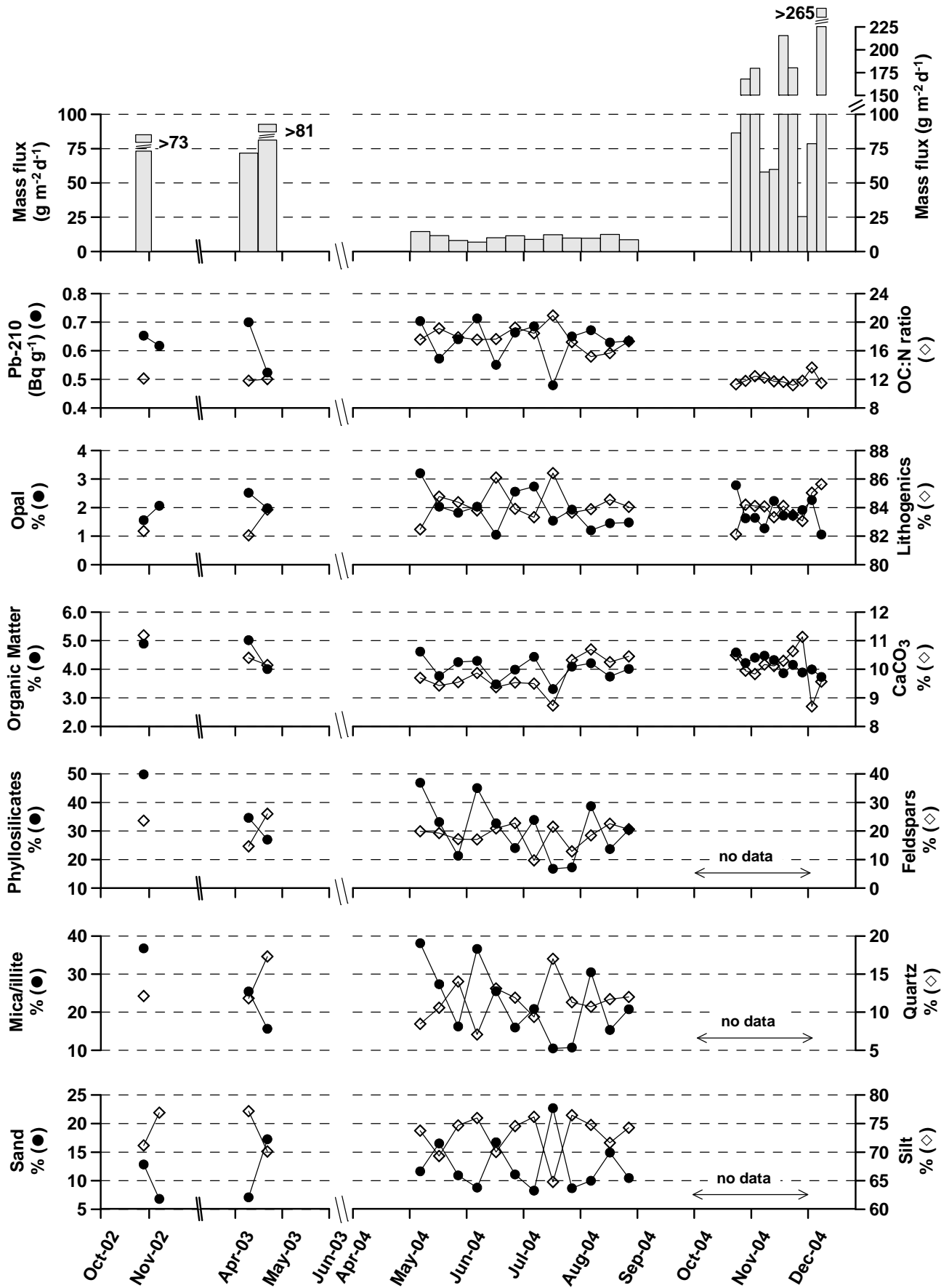

Fig. 2. Time series of mass flux and major constituents (as percentage dry weight), ${ }^{210} \mathrm{~Pb}$ total concentration, mineralogy and granulometry (sand and silt content) of sediment trap samples from trap T1 (1600 m depth). The width of the columns represents the time interval integrated by each sediment trap sample. Episodes of trap overfilling are indicated by broken bars and the minimum flux (the flux measured until the time of overfilling) is reported in $\mathrm{g} \mathrm{m}^{-2} \mathrm{~d}^{-1}$. The trap was installed at 25 mab during the first and second deployment periods and at 50 mab thereafter. Sampling intervals and other details are provided in Table 1. Feldspars are considered the sum of Kfeldspars and plagioclase; the reported phyllosilicates are the sum of chlorite, kaolinite and mica/illite. 
Figure 3
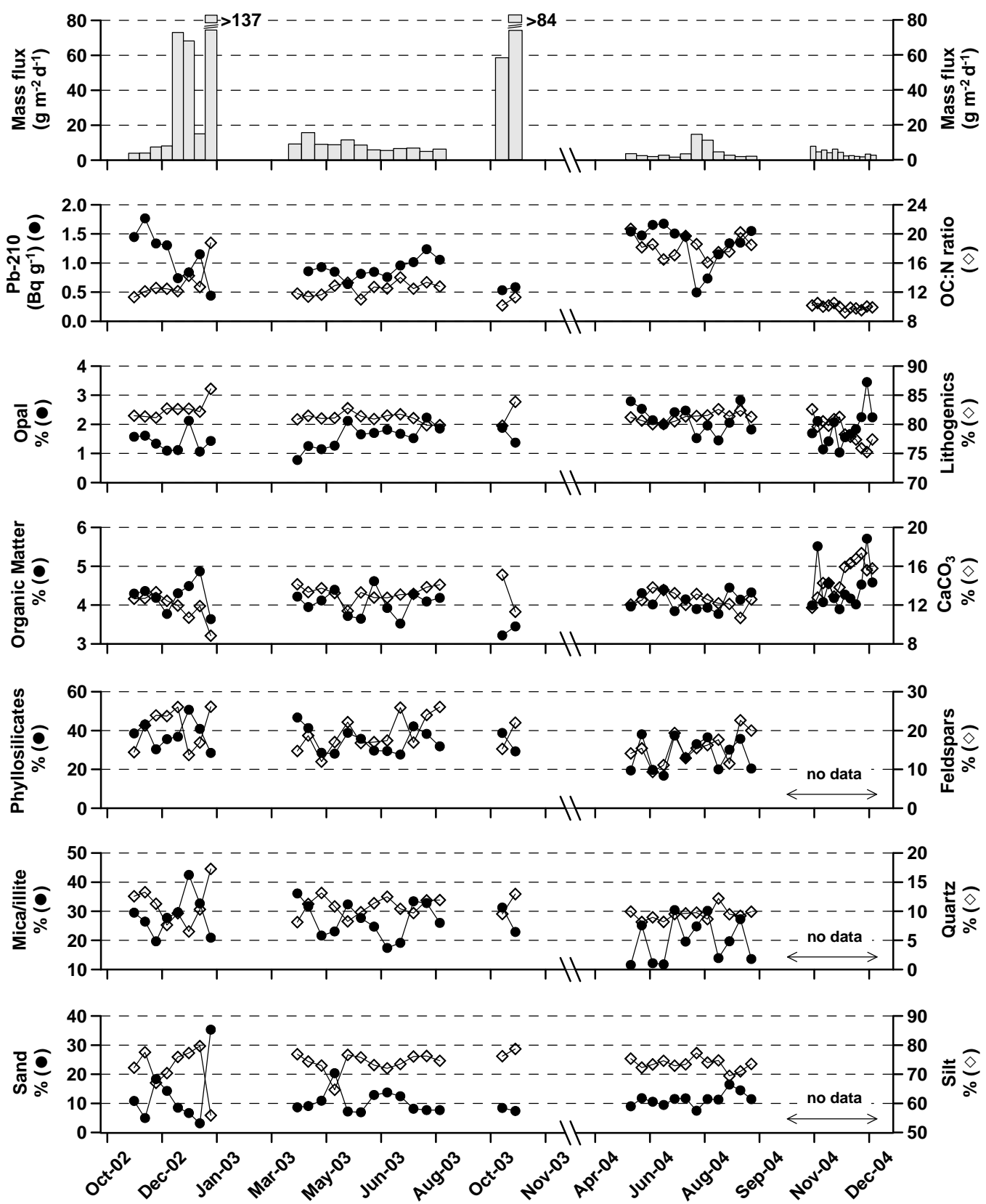

Fig. 3. Time series of bulk mass flux, major constituents (as percentage dry weight), ${ }^{210} \mathrm{~Pb}$ total concentration, selected minerals and sand and silt contents of trap T2 samples (3300 m depth; $25 \mathrm{mab}$ ). Trap overfilling episodes are indicated by a broken bar and the minimum flux is reported in units of $\mathrm{g} \mathrm{m}^{-2} \mathrm{~d}^{-1}$. Feldspars are considered the sum of K-feldspars and plagioclase; the reported phyllosilicates are the sum of chlorite, kaolinite and mica/illite. 
Figure 4

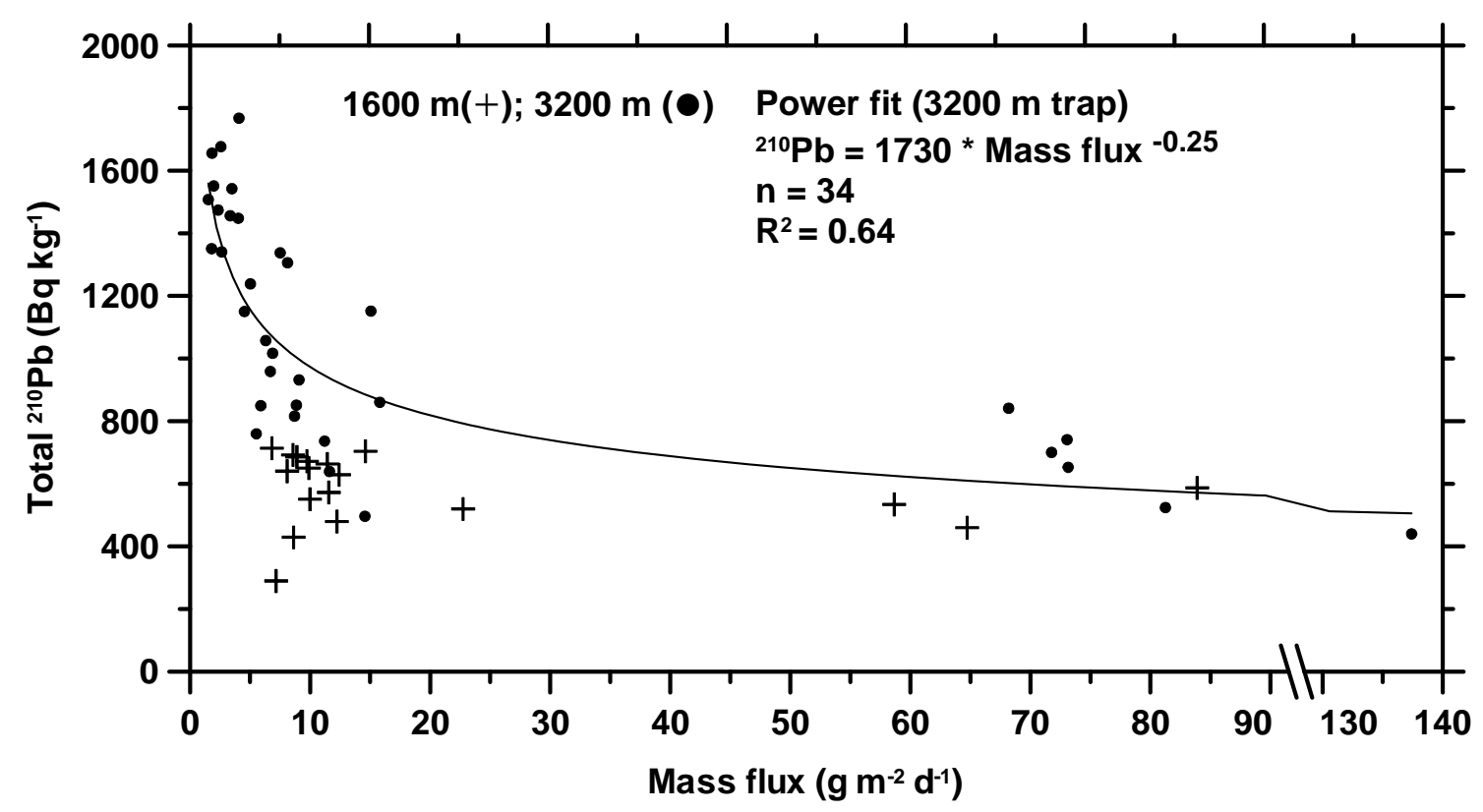

Fig. 4. Relationship between ${ }^{210} \mathrm{~Pb}$ specific activity and settling particle flux in sediment trap samples from the Nazaré Canyon. 
Figure 5
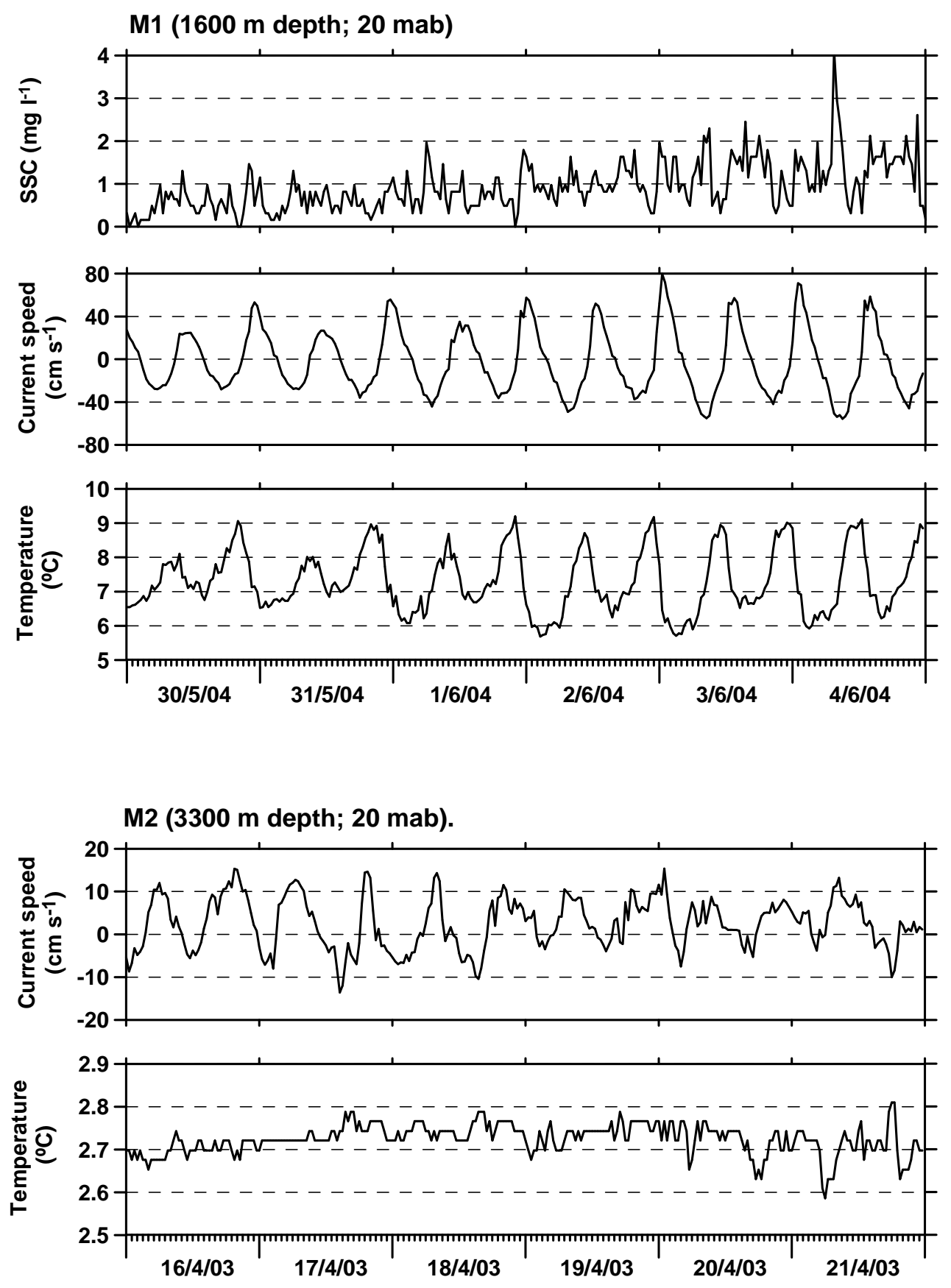

Fig. 5. Time-series of salinity, temperature and current speed recorded $20 \mathrm{~m}$ above bottom at sites M1 (top) and M2 (bottom). Suspended sediment concentration is also shown at M1. Two short representative periods have been selected in each case. 


\section{Figure 6}
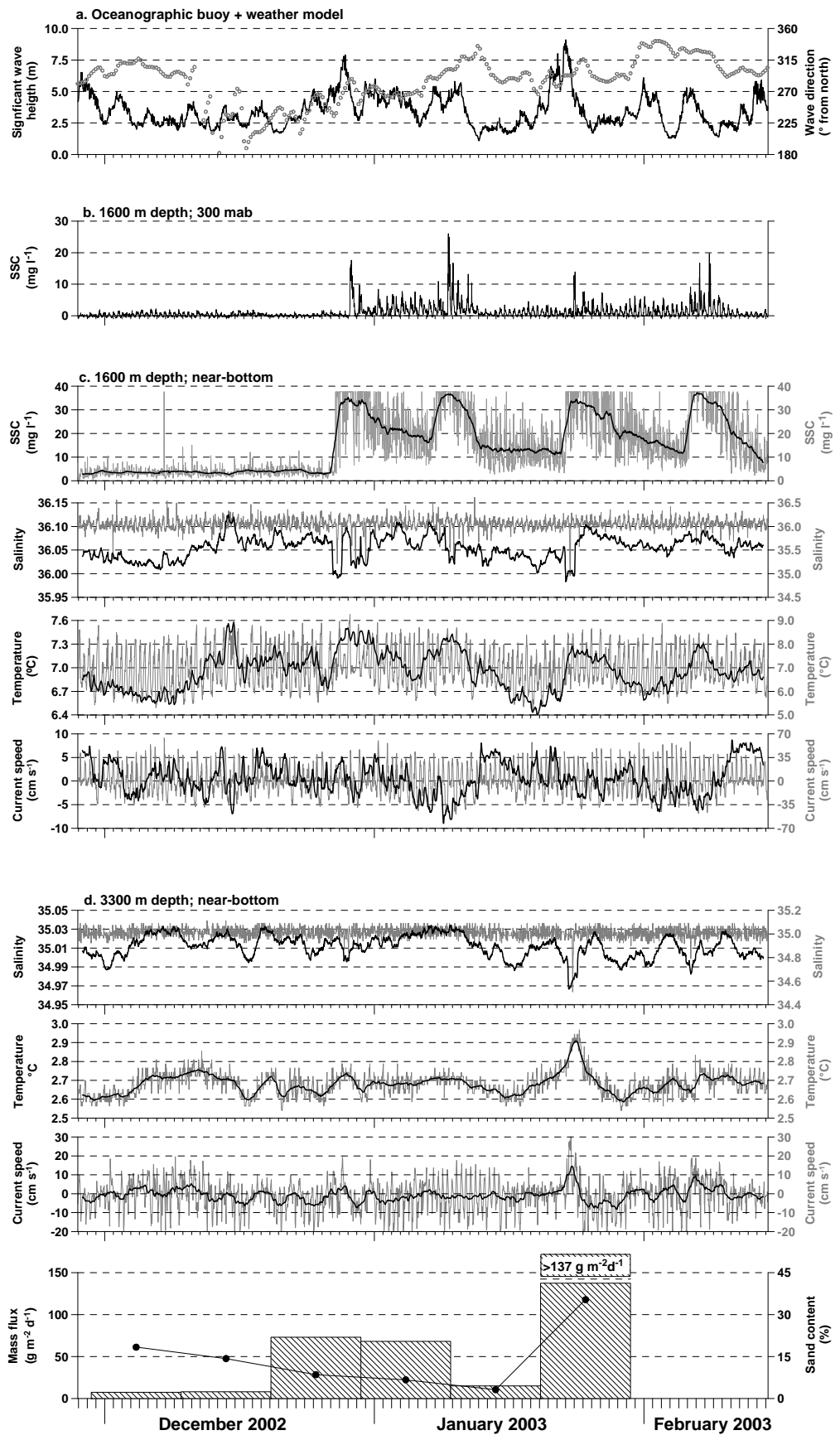

Fig. 6. Time-series of available oceanographic, hydrodynamic, nephelometric and mass flux measurements during late autumn 2002-winter 2003. a: significant wave height (line) from the oceanographic buoy and wave direction (open circles) measured in degrees from north, obtained from the Wavewatch 3 model; b, c, d: RCM and sediment trap data. A low pass filter (window $=25$ hours; bold line in the graph) was applied to near-bottom hydrodynamic, hydrographic and turbidity data in order to filter supradiurnal (mainly tidal) oscillations (black line). The original data (sampling rate $=$ $30 \mathrm{~min}$ ) is shown by the grey line. Current speed corresponds to the along-canyon component after rotating the velocity vector to fit the approximate direction of the canyon axis at each station (positive values are down-canyon). SSC $=$ suspended sediment concentration. 


\section{Figure 7}
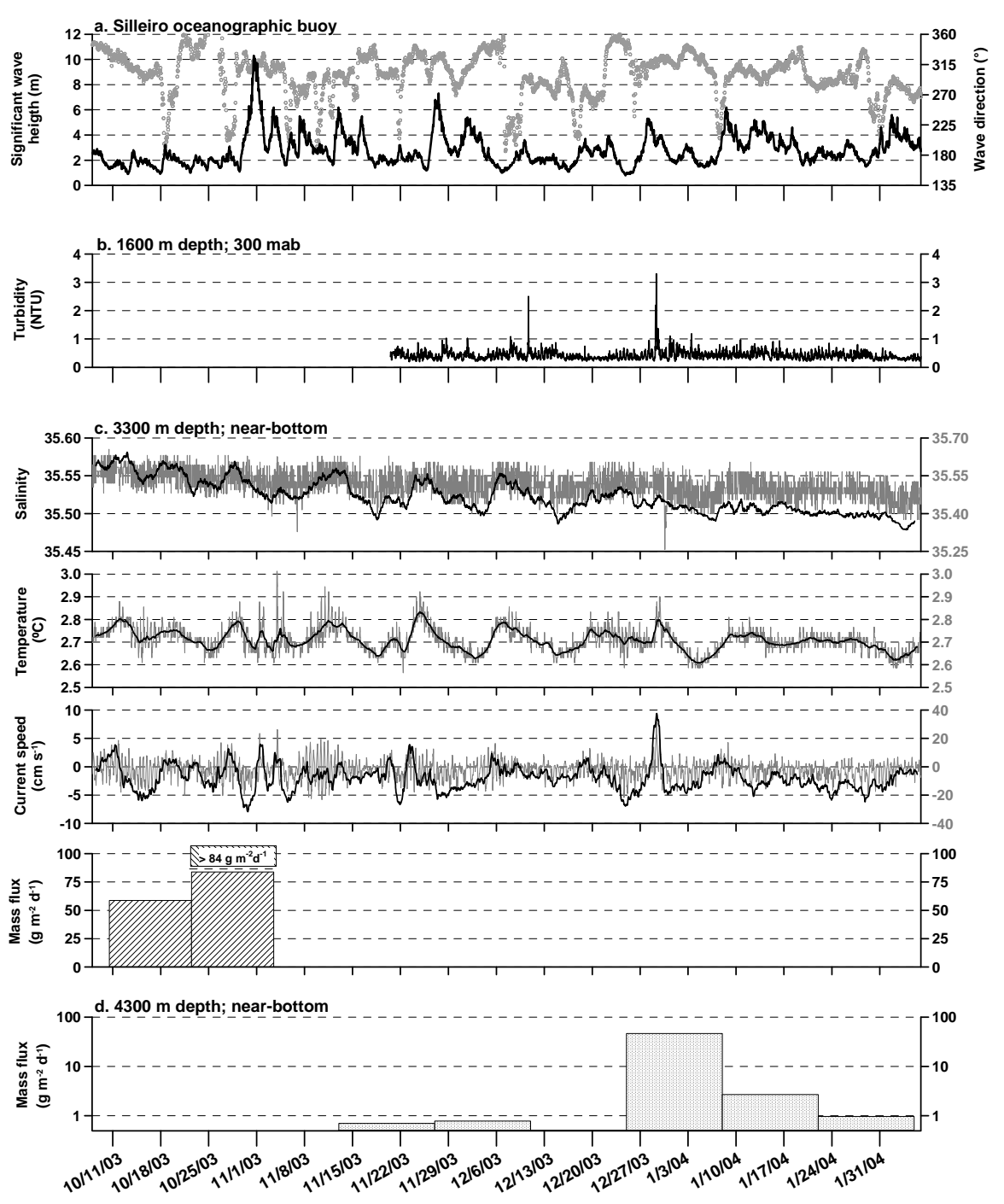

Fig. 7. Time-series of oceanographic, hydrodynamic, nephelometric and mass flux measurements available for autumn-winter 2003. a: significant wave height (line) and mean wave direction (open circles) from the Silleiro oceanographic buoy; b: water turbidity at $300 \mathrm{mab}$ over $1600 \mathrm{~m}$ total water depth; c: Current speed, temperature, salinity and apparent mass flux near the bottom at $3300 \mathrm{~m}$ depth. For near-bottom RCM data, the right axis relates to the original data (resolution $30 \mathrm{~min}$ ) and left axis for lowpass filtered (25h) data. d: Mass flux measured by a near-bottom trap deployed in the lower canyon axis (4300 m depth, see De Stigter et al., 2007 for details). Note the logarithmic scale for the deepest trap. 


\section{Figure 8}
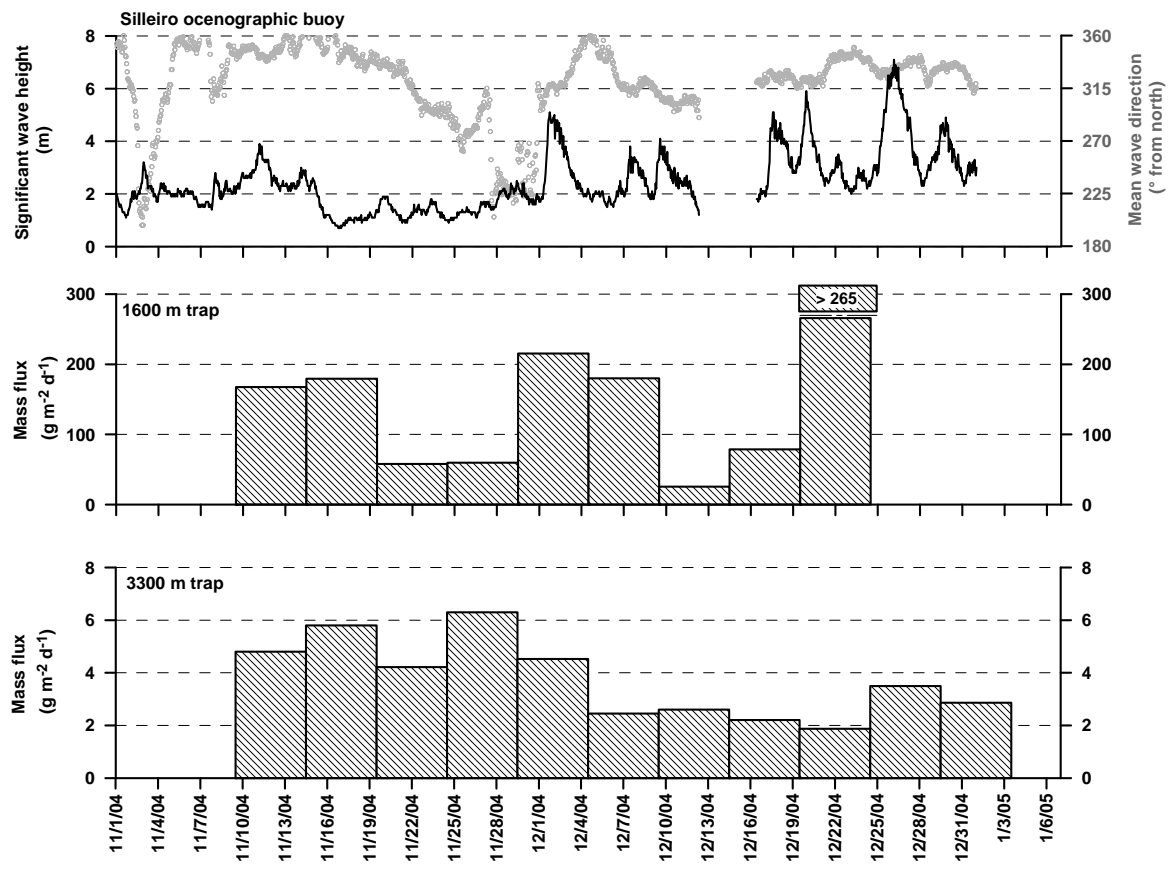

Fig. 8. Time-series of wave data and downward particle fluxes in the Nazaré submarine canyon during autumn-winter 2004. 


\section{Figure 9}

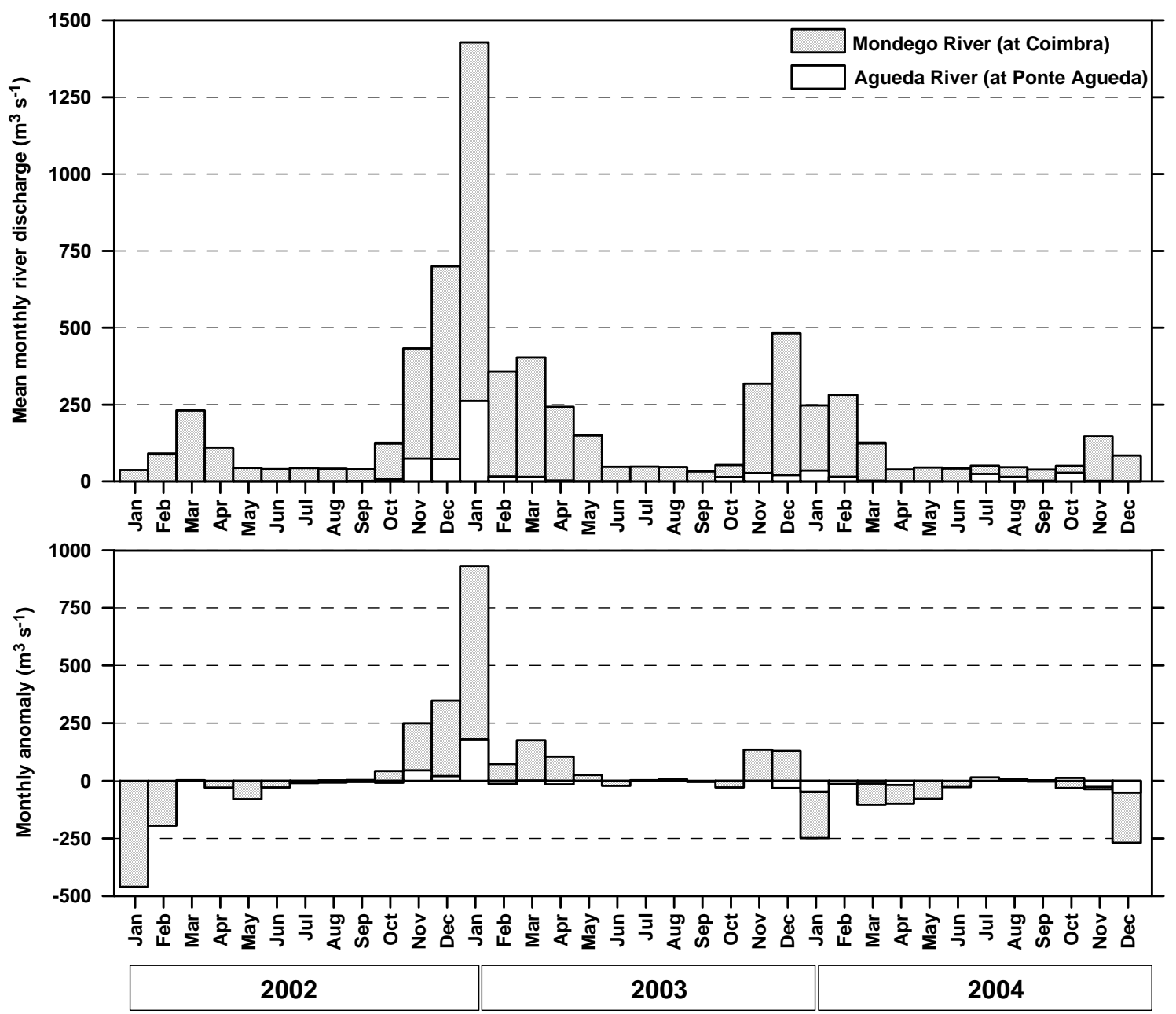

Fig. 9. Top: mean monthly water discharge of the Mondego and Agueda rivers during the study period. Bottom: monthly anomalies with respect to the interannual mean (1990-2009 for the Mondego River; 2001-2009 for the Agueda River). 


\section{Table 1}

\begin{tabular}{|c|c|c|c|c|c|c|c|c|}
\hline Deployment & Sampling dates & Latitude & Longitude & Sampling & Depth & mab & Mean speed & Max. speed \\
\hline & & & & interval (d) & (m) & (m) & $\left(\mathrm{cm} \mathrm{s}^{-1}\right)$ & $\left(\mathrm{cm} \mathrm{s}^{-1}\right)$ \\
\hline I & 09/11/2002 - 19/11/2002 & $39^{\circ} 31^{\prime} 22^{\prime} \mathrm{N}$ & 9³1'51'W & 10 & 1630 & 25 & 16.6 & 64.1 \\
\hline II & $28 / 04 / 2003-22 / 05 / 2003$ & $39^{\circ} 31^{\prime} 30^{\prime \prime} \mathrm{N}$ & $9^{\circ} 32^{\prime} 42^{\prime \prime} \mathrm{W}$ & 12 & 1604 & 25 & 25.5 & 75.3 \\
\hline III & - & $39^{\circ} 31^{\prime} 06^{\prime \prime} \mathrm{N}$ & $9^{\circ} 32^{\prime} 52^{\prime \prime} \mathrm{W}$ & 12 & 1525 & 50 & no data & no data \\
\hline IV & $20 / 05 / 2004-17 / 09 / 2004$ & $39^{\circ} 31^{\prime} 22^{\prime \prime} \mathrm{N}$ & $9^{\circ} 32^{\prime} 48^{\prime \prime} \mathrm{W}$ & 10 & 1610 & 50 & 26.7 & 80.7 \\
\hline $\mathbf{V}$ & 05/11/2004 - 04/01/2005 & $39^{\circ} 31^{\prime} 18^{\prime \prime} \mathrm{N}$ & $9^{\circ} 32$ '50'W & 5 & 1600 & 50 & no data & no data \\
\hline $\mathbf{I}$ & 09/11/2002 - 28/01/2003 & $39^{\circ} 30^{\prime} 24^{\prime} \mathrm{N}$ & $9^{\circ} 51^{\prime} 44^{\prime \prime} \mathrm{W}$ & 10 & 3350 & 25 & 8.0 & 30.7 \\
\hline II & $16 / 04 / 2003-26 / 08 / 2003$ & $39^{\circ} 30^{\prime} 18^{\prime \prime} \mathrm{N}$ & $9^{\circ} 52^{\prime} 00^{\prime \prime W}$ & 12 & 3270 & 25 & 7.4 & 27.3 \\
\hline III & $10 / 10 / 2003-03 / 11 / 2003$ & $39^{\circ} 30^{\prime} 02^{\prime \prime N}$ & $9^{\circ} 52^{\prime} 19^{\prime \prime W}$ & 12 & 3250 & 25 & 7.5 & 32.5 \\
\hline IV & $20 / 05 / 2004-17 / 09 / 2004$ & $39^{\circ} 30^{\prime} 04^{\prime} \mathrm{N}$ & $9^{\circ} 52^{\prime} 05^{\prime \prime} \mathrm{W}$ & 10 & 3250 & 25 & 8.9 & 32.5 \\
\hline $\mathbf{V}$ & 05/11/2004 - 04/01/2005 & $39^{\circ} 30^{\prime} 12^{\prime \prime} \mathrm{N}$ & $9^{\circ} 52^{\prime} 16^{\prime \prime} \mathrm{W}$ & 5 & 3270 & 25 & no data & no data \\
\hline
\end{tabular}

Table 1. Sampling dates, geographical locations and depths of sediment traps deployed in the Nazaré submarine canyon. 'mab' stands for distance of the traps above the seafloor. Mean and maximum current speed, measured by current meters installed 5 meters below the traps, are also shown. 